Araștırma Makalesi - Gönderim Tarihi: 26.02.2018 Kabul Tarihi: 16.04. 2018

\title{
Sosyal Medya Kaynaklı Krizlerin 'İmaj Restorasyon Teorisi’ Açısından Örnek Olaylar Üzerinden İncelenmesi
}

\author{
Özlem Duğan ${ }^{1}$
}

Öz

Krizler geleneksel medya dışında artık sosyal medyaya da yansımaktadır. Dolayısıyla krizlerin yayılımı çok hızı ılmakta ve geniş kitlelere kısa sürede ulaşmaktadır. Kısa sürede hedef kitleye açıklama yapılması zor aynı zamanda süre gerektiren bir durumdur. Krize tepki stratejilerinin bu süreçte iyi seçilmesi, kriz ile ilgili açıklamaların zamanında yapılması, sosyal medyada kriz ile ilgili öneri, şikayet ve yorumların iyi analiz edilmesi gerekir. Sosyal medya kaynaklı krizlerin önceden öngörülmesi, kriz senaryolarının belirlenmesi, kriz planının hazırlanması, kriz ekibinin oluşturulması zaman kaybetmeden yapılması gereken halkla ilişkiler çalışmalarıdır. Krizi önceden sezinleyerek proaktif bir yaklaşım sergileyen halkla ilişkiler birimlerinin başarılı olduğu bilinmektedir. Bu bağlamda sosyal medyayı iyi yöneten kurumların krizi daha kolay atlattıkları görülmektedir. Bu çalışmada sosyal medyada meydana gelen başka bir ifadeyle sosyal medya kaynaklı krizler imaj restorasyon teorisi çerçevesinde incelenmiştir. Dünyanın çeşitli ülkelerinde ve Türkiye'de sosyal medyada paylaşılan mesajların içerikleri incelenmiş ve sosyal medyada paylaşılan mesajlar nedeniyle meydana gelen 19 kriz belirlenmiştir. Sosyal medya kaynaklı krizlerin seçilme nedeni, günümüzde kurumların artık sosyal medyada paylaşılan içerikler nedeniyle de kriz ile karşı karşıya kalmalarıdır. Çalışma sonucunda kurumların çoğunlukla özür dileme stratejisini kullanarak tepkiyi azaltmaya çalıştıkları, krize neden olan kişiyi kurumdan uzaklaştırmak amacıyla ilgi kesme stratejisini kullandıkları ve krize neden olan mesajı sosyal medya hesabından silme stratejisini tercih ederek krizin etkisini azaltmaya çalıştıkları ve krizi bir daha yaşamamak için düzeltici eylem stratejisini kullandıkları belirlenmiştir.

Anahtar Kelimeler: Sosyal Medya, Kriz Yönetimi, İmaj Restorasyon Teorisi, Örnek Olaylar

Atıf: Duğan, Özlem. (2018) Sosyal Medya Kaynakıı Krizlerin 'İmaj Restorasyon Teorisi' Açısından Örnek Olaylar Üzerinden İncelenmesi. Akdeniz Üniversitesi Illetișim Fakültesi Dergisi, (AKIL) Haziran (29) s. 293-313

1 Dr.Öğr.Üyesi, Uşak Üniversitesi, İletişim Fakültesi, Halkla İlişkiler ve Reklamcılık Bölümü. ozlem.dugan@ usak.edu.tr 


\title{
The Investigation of Social Media Crises From the Viewpoint of 'Image Restoration' Theory via Case Studies
}

\begin{abstract}
Crises are reflected on social media beside traditional media nowadays. Hence, crisis spreads in social media very fast and social media has a disadvantage in reaching to wide masses in short time. Making a statement to the target audience in a short period of time is very hard and requires time. Reaction strategies must be chosen carefully in this process, explanations on the crisis need to be on time, and suggestions, complaints and comments about crisis in social media must be well analyzed. Forescasting crises originating from social media, designation of crisis scenarios, , preparation of a crisis plan and building a team to tackle the crisis are public relation works to be done without losing time. It is known that public relations units which predict and show an proactive approach to crisis excel at managing crises.In this context, it is observed that institutions that manage social media better manage crisis more easily. In this study, social media originated crises were examined in the context of image restoration theory. Posts that shared in social media in several countries across the world and Turkey are examined and 19 crisis events occurring due to posts that shared in social media are determined. The reason for the selection of crises originating from social media is that organizations also come up against crises that arise due to contents also shared in social media. Results indicate that organizations mostly try to reduce the reaction by using apology strategy, they use the eviction strategy to dismiss the person who caused the crisis, and they prefer the strategy of deleting the message caused the crisis from social media accounts in order to take corrective action and to reduce the efffects of crisis for the sake of not facing a crisis again.
\end{abstract}

Keywords: Social Media, Crisis Management, Image Restoration Theory, Case Studies 


\section{Giriș}

$\mathrm{K}$ riz aniden ortaya çıkan, kurumlarda ve bireylerde strese neden olan, kurumların işleyişini bozan olumsuz durumlardır. Krizler, gelişen teknoloji ile birlikte sadece geleneksel medya ile ortaya çıkmamakta, sosyal medya aracılığıyla hızla yayılmaktadır. Hızlı ve ucuz olması, kısa sürede geniş kitlelere ulaşması, çift yönlü olması, kurumların tanıımına katkısı göz önüne alındığında sosyal medyanın kurumlar için önemi ortaya çıkmaktadır. Kurumların yanı sıra bireyler, bireysel olarak sosyal medyanın özelliklerinden faydalanmaktadır. Hedef kitleler pasif değil, daha etkin ve katılımcıdır. Hedef kitleler sosyal medya aracılığıyla fikirlerini ve tepkilerini dile getirebilmektedir (Tekvar, 2016: 200). Sosyal medya ile markalar, kurumlar ve liderler imajlarına yönelik olumlu izlenimleri çok hızlı ve çok geniş kitlelere etkileşim içerisinde sunabilmektedir (Alikılıç, 2011: 20). İletişim teknolojisindeki gelişmeler kurumların en önemli birimleri arasında yer alan halkla ilişkilere çevrimiçi chat odaları, e-posta, etkileşimli röportajlar, basın konferansları ve anketler gibi yöntemlerle hedef kitlelere doğrudan ulaşma imkânının yanı sıra video, resim, metin ve ses paylaşımına olanak sağlamaktadır (Harris ve Whalen, 2009: 54; Scott, 2010: 38). Kamuoyu oluşturma ve yönlendirmede etkili olan (Koçak, 2016: 224) sosyal medya, kullanıcılara düşünce ve bilgi paylaşım fırsatı sunarak, etkileşim yaratır (Sayımer, 2008: 123). Ancak sosyal medyanın avantajlarının yanında dezavantajları vardır. Kurumlar sosyal medyayı iyi yönetemediği zaman itibar kaybına uğrayabilirler. Sosyal medyanın hızlı olması ve kısa sürede geniş kitlelere ulaşması kurumun mesajlarını kısa sürede hedef kitleye ulaştırmasını gerektirir. Bu durum çeşitli nedenlerle mümkün olmayabilir. Sosyal medyada takipçilerin olumsuz yorumlarını, görüşlerini ve fikirlerini ifade etmesi ve bunun hızla yayılması kuruma zarar verebilir. Bu bağlamda kurum ve kuruluşlar, iletişim ve halkla ilişkiler ajansları, halkla ilişkiler çalışanları iletişim stratejilerini planlarken hedef kitlenin beklentilerini fark ederek öngörülerini geliştirmelidir. Bu nedenle kurumlar, hedef kitlelerine yönelik olarak sosyal medyayı profesyonel bir şekilde yönetmeli ve kullanmalıdır (Tekvar, 2016: 210). Bu çalışmada sosyal medya kaynaklı krizler örnek olaylar üzerinden imaj restorasyon teorisi çerçevesinde incelenmiştir. Krizin hangi sosyal medya aracında meydana geldiği, krizin hangi mesaj ya da olayla ortaya çıktığı, kurumun krize tepki stratejileri incelenmiş, çalışma örnek olaylar üzerinden elde edilen veriler doğrultusunda değerlendirilmiştir.

\section{Sosyal Medyada Kriz Yönetimi}

Kriz, aniden meydana gelen kötüye gidiş, buhran olarak tanımlanmaktadır. Kriz, reform gerektiren istikrarsız bir durumu ifade etmektedir. Kriz, kurumun performansını olumsuz şekilde etkileyen ve hedeflerini tehdit eden bir süreçtir (Tüz, 1996: 3; Coombs, 2006: 2; Pira ve Sohodol, 2004: 23). Çince'de kriz tehlike ve fırsat anlamına gelmektedir (Okay ve Okay, 2007: 73). Başka bir ifadeyle krizin içerisinde tehdit de vardır fırsat da. Önemli olan kurumun krizi başarılı bir şekilde yönetip yönetemediğidir. Krizin başarılı bir şekilde yönetilmesi için krizin nedenlerini iyi analiz etmek gerekir. Krizin ortaya çıkış nedeni çok çeşitli olabilmektedir. Krize neden olan faktörler, çevresel faktörler ve örgütsel faktörler olarak iki başlıkta ele alınabilir (Okay ve Okay, 2013: 352). Kurumun dışında gelişen, sosyal, ekonomik, kültürel ve hukuki politikalar çevresel faktörlerdendir. Örgütsel faktörler, kurumun işleyişi, çalışanların ve yöneticilerin tutum ve davranışları nedeniyle yaşanabileceği gibi fiziki koşulların yetersizliği nedeniyle ortaya çıkabilir (Çetin ve Toprak, 2016: 56). Krizin ortaya çıkış nedenleri arasında teknolojideki 
değişimler, hukuk ve politika alanında yapılan yeni düzenlemeler, sosyal, kültürel faktörlerdeki değişiklikler, pazardaki rekabet, kaynak sıkıntısı, doğal afetler, üretim ya da ürün sorunları, endüstriyel kazalar, yönetim sorunları, yolsuzluklar yer almaktadır (Haşit, 2013: 3). Kuruma karşı açılan davalar, olumsuz içerikli medya yayınları, tüketici boykotları hem krize neden olabilecek hem de krizin sonuçları olabilecek olumsuz durumlardır (Goodman, 2006: 202). Krizin nedenleri arasında kurumda çalışanların veya yöneticilerin sosyal medyada paylaştıkları mesajlar olabilmektedir. Bu bağlamda mesajın yanlış anlaşı Iması, mesajın hedef kitleye doğru şekilde iletilememesi, paylaşılan mesajın zamanının yanlış seçilmesi, tepkilere zamanında ve doğru yanıt verememe, hedef kitlenin gündemini takip edememe gibi çeşitli nedenler sosyal medyada krize yol açabilmektedir. Sosyal medyada doğan krizlerin en önemli tehlikesi çok hızlı gelişmesidir. İçeriğin kontrolsüzce üretilmesi ve dağıtılması bu durumun nedenidir (Suher, 2013: 136). Tüm dünyada birçok insana ulaşabilecek doğrulanmamış bilginin hızla yayılması, bu yanlış bilginin panik yaratma tehlikesi ve bu süreçte zamanın kısıtlı olması (Çınarlı, 2016: 69; Valentini ve Kruckeberg, 2016: 15), krizin yönetimini zorlaştırmaktadır. Kriz yönetimi, krizi ortadan kaldırmak için planlı, sistematik, ve rasyonel kararları almak ve uygulamaktır. Alınan kararların uygulanması, bu kararları uygulayacak ekibin oluşturulması ve ekibin kriz sona erene kadar aktif çalışmasını gerektirir (Pira ve Sohodol, 2004: 183; Tüz, 2004: 85). Kriz iletişimi, herhangi bir kriz döneminde bilginin toplanması, işlenmesi ve dağıtılmasıdır (Coombs, 2010: 20).

İletişim, kriz yönetiminde dikkatli ve özenli kullanılmalıdır. Kriz iletişiminde sosyal medyayı da iyi analiz etmek gerekmektedir. Sosyal medyada meydana gelen krizleri yönetmek için sosyal medyanın avantaj ve dezavantajlarını iyi bilinmelidir. Özellikle kriz zamanında sosyal medya aracılığıyla güvenilir bilgileri ve haberleri sunmak kurumlar için büyük avantajdır (Jensen, 2014: 7). Kurumlar, sosyal medya aracılığıyla krizle ilgili anlatmak istediklerini kamuoyuna çok hızlı bir şekilde ulaştırabilmektedir (Perry vd., 2003: 227; Sweester ve Metzgar, 2007: 342; Okay ve Okay, 2007: 345; Yoo vd., 2016: 132). Sosyal medya, bilginin her zaman güncellenmesini sağlaması açısından kriz dönemlerinde en doğru bilginin bulunabileceği yerdir (Aslan, 2015: 18). 2015'te Paris Bataclan'da terör saldırılarından sonra Facebook, güvenlik durumu kontrolünü aktif hale getirmiştir. Bu uygulama 2011 yılında Japonya'da yaşanan deprem ve ardından gelen tsunami sonrasında bir proje geliştirmeye başlanmış ve yine iki doğal afette; Ekim 2015'teki Patricia tayfununda (Çınarlı, 2016: 71) ve 2015'te Nepal'de yaşanan deprem gibi sosyal medya aracılığıyla elde edilen bilgiler, depremde yakınını arayan, depremzedelere yardım etmek isteyenlere bilgi akışı sağlamıştır (Andrews vd., 2016: 288). Kriz dönemlerinde, krizi başarıyla yönetebilmek için krize tepki stratejilerini iyi seçmek ve uygulamak önemlidir. Hedef kitleyi çok iyi analiz ederek, stratejileri zamanında kullanarak, hedef kitleden tepki almayacak şekilde krizi yönetmek gerekir. Çin'deki Alibaba şirketinin yaşadığı krizin incelendiği çalışmada, kriz döneminde iyi bir iletişim tarzını seçme, toplumsal duyguları analiz etme, kendi ile alay etme (selfmocking) tepki stratejisini kullanan CEO'nun başarılı olduğu belirlenmiştir. CEO, mizahi kullanarak krize tepkileri hafifletmekle kalmamış, potansiyel bir itibar kazanmış, krizi şirket için olumlu bir halkla ilişkiler fırsatı haline dönüştürmüştür (Kim vd., 2016: 904).

Kriz esnasında krizin olumsuz etkisini azaltmak, halkın sempati ve desteğini kazanmak için "sevimli davranma" tekniğinin etkili olduğu yapılan çalışma ile ortaya konmuştur (Wang, 2016: 56). Sosyal medya hem krizin yaratıcısı hem de krize tepki vermek ve krizin etkilerini hafifletmek için bir araçtır (Maresh-Fuehrer, 2016: 627). Bu aracı 
doğru kullanarak mesajları zamanında iletmek gerekir. Liderler de sosyal medyayı doğru kullanmak durumundadır. Sosyal medyayı iyi yöneten liderlerin krizi kısa sürede atlatmada etkili olduğu bilinmektedir. Sosyal medya doğru ve zamanında kullanıldığında liderlere de büyük avantaj sağlamaktadır (Sayar ve Duğan, 2017: 312). Kriz yönetimi ve liderlik konusunun Twitter örneği üzerinden incelendiği bir çalışmada liderlerin farklı seslere önem vermesinin ve krize cevap verme yeteneğinin önemli olduğu tespit edilmiştir (Gruber vd., 2015: 171). Bilinçli şekilde yönetilemeyen sosyal medya hem krize neden olmakta hem de krizin büyümesini tetikleyebilmektedir. Krizin yönetilmesinde önemli rol oynayan sosyal medya dikkatli kullanılmalıdır (Kalaycı, 2017: 333). Bunlardan en önemlisi dürüstlük ve samimiyettir. Kurumlar krizde hedef kitlelerine karşı dürüst ve samimi oldukları zaman krizi atlatma süreçleri kolaylaşmaktadır. Bu nedenle doğru bilgiler sosyal medya aracılığıyla paylaşılmalı, sosyal medyadaki yanlış bilgiler takip edilmeli ve düzeltmelidir (Lin vd., 2016: 3-4; Suher, 2013: 138139). Ayrıca kriz ekibi lideri, kurum sözcüsü ya da CEO, hedef kitleye ne söylenmesi gerektiğini iyi bilmelidir (Grundy ve Moxon, 2013: 55-61). Hedef kitlenin tepkisini çekecek, hedef kitlenin hassas olduğu konularda içerik paylaşırken çok dikkatli olunmalıdır. Zamanında, doğru ve güncel bilgilerin sosyal medya aracılığıyla hedef kitleye, paydaşlara, tedarikçilere ulaştırılması krizin yönetilmesini kolaylaştıracaktır. Kriz ekibinin en üst kademede ve tek merkezde toplanması krizin başarılı şekilde yönetilmesinde etkilidir. Kriz ekibine özellikle sosyal medya krizleri ile ilgili sürekli eğitim verimesi faydalı olacaktır. Kadıbeşegil'e göre kriz dönemleri kurumların saniyelerle yarıştığı dönemlerdir. Bu dönemlerde kriz ekibi sürekli yeni bilgilerle beslenmeli ve yeni bilgiler üretmelidir (Kadıbeşegil, 2003: 135).

Sosyal medyada kriz iletişiminin etkili olması için Sherman (2010) 4 öneri sunmuştur. İlk olarak kriz kabul edilmeli ve hata için özür dilenmelidir. İkinci olarak sorunun hemen çözüleceği ve çözüldüğü anda herkese duyurulacağı bildirilmelidir. Üçüncü olarak sorun ile ilgili yorum yazan, içerik oluşturan takipçilere özel mesaj hazırlanmalı, atılmalı ve ardından sorunun giderildiği duyurulmalıdır. Son olarak, sosyal medya aracılığıyla ulaşılması mümkün olmayan kişilerin, posta adreslerine veya başka sosyal ağ hesaplarına ulaşarak bilgi verilmelidir (Suher, 2013: 140-141).

Krizde kullanılan stratejilerden biri sosyal medya takipçilerinin şikayetlerini önemsemek ve çözüm üretebilmektir. Mitroff (2001), şikayetlere karşı sosyal medyada hızla yayılan olumsuz haberlere yönelik yanlış anlamaların düzeltilmesini, kamuoyuna yapılacak açıklamanın kibar bir dille yapılmasını, kamuoyuna verilen mesajda mesleki jargonunun kullanılmamasını, müşteri haklı ise sorun kabul edilerek çözüm odaklı davranılmasını, tüketici yorumlarının önemsenmesini ve konu ile ilgili gereken önlemlerin alınmasını önermektedir. Ancak bir şirketin olası tüm krizleri önceden tahmin etmesi ve krizi önlemeye yönelik tedbirler alması mümkün değildir (Kırdar ve Demir, 2007: 94). Bu nedenle kriz ortaya çıktıktan sonra krizin doğru stratejilerle ve doğru zamanda yönetilmesi önem taşımaktadır. Bu kapsamda halkla ilişkiler çalışmaları kriz yönetiminin önemli bir bölümünü oluşturmaktadır. Kriz öncesi dönemde yapılacak proaktif halkla ilişkiler krizi öngörecek, krizi önlemeye çalışacak, kriz ortaya çıkarsa çözüm yöntemi üretecektir. Krizin etkisini, belirsizliklerini ve bilgi eksikliğini azaltmaya çalışan halkla ilişkiler birimleri krize neden olabilecek dedikoduları önlemeye çalışmalı, yanlış anlamaları en aza indirmek için bilgileri sürekli medya ile paylaşmalıdır. Sosyal medyada takipçilerin paylaştığı içerikler önemsenmeli, kriz ile ilgili açıklamayı en yetkili kişi yapmalı, açıklamaların sadece hedef kitleye değil medyaya da yapıldığı göz önünde 
tutulmalıdır. Sosyal medyayı müşteriyi anlayan ve dinleyen, sabırlı, sakin, samimi ve takipçilerin tepkilerine önem veren sosyal medya uzmanlarının görevlendirilmesi kriz yönetiminin başarılı olmasına etkili olacaktır. Kurumlar (Canpolat, 2012: 132) krizi etkili bir şekilde yönettiklerinde imajlarını ve itibarlarını koruyabilmektedirler.

\section{2. İmaj Restorasyon Teorisi}

İmaj bireyler kadar kurumlar için de önemli bir kavramdır. Hiç kimse ya da hiçbir kurum imajının kötü olmasını arzu etmez. Ancak kriz dönemlerinde olumlu imaj bir anda olumsuz bir imaja dönüşebilir. Kurumlar bu dönemlerde imajlarını düzeltmeye yönelik birçok strateji kullanırlar. İmaj restorasyon teorisinin amacı imajı olumlu yönde düzeltme stratejileridir. İmajı yeniden yapılandırma teorisi William Beneoit tarafından geliştirilmiştir. 2005 yılında teorinin adı imajı yeniden yapılandırma teorisi (image restoration theory) olarak kabul edilmiştir. Kurumun itibarını tehdit eden bir saldırı durumunda kullanılan imaj restorasyon teorisi, kuruluş itibarını ve imajını neyin tehdit ettiğini, hangi kitlelere hitap edileceğini ve kimin ikna edileceğini belirler. Teorinin amacı olumlu imajı korumak ve yeniden inşa etmektir (Çınarlı, 2016: 49-50). Teori kurumsal özür dilemenin genişletilmiş biçimidir. Kurumun imajı büyük oranda güvenilirliği ile ilişkilidir ve kurumların imajını kaybetmemesi için gösterdikleri çabaları ifade etmektedir (Low vd., 2011: 218-242). Teori, ayrıca kurum yöneticilerinin karşılaştıkları sorunları önceliklerine göre belirlemeleri ve sorunları gidermeye yönelik kullandıkları iletişim dili ve iletişim araçlarını belirleyebilme olanağı sunmaktadır (Çetin ve Toprak, 2016: 58). Imaj restorasyon stratejisi inkar, sorumluluktan kaçma, eylemin olumsuzluklarını azaltma, düzeltici eylem ve kabullenme olmak üzere beşe ayrılmıştır (Coombs ve Schmidt, 2000: 165).

Tablo-1: İmaj Restorasyon Stratejileri ve Temel Özellikleri

\begin{tabular}{|l|l|}
\hline STRATEJi & TEMEL ÖZELLiK \\
\hline 1. İnkar & \\
\hline 1.1.Basit İnkar & Kurumun, herhangi bir hata olmadığını ileri sürmesi \\
\hline 1.2. Suçu Bașkasına Atma & Kurumun hatanın bașkası tarafından yapııı̆ı̆ııı ileri sürmesi \\
\hline 2. Sorumluluktan Kaçma & \\
\hline 2.1.Provokasyon & Kurum hatanın anlașılabilir karșılanmasını sağlamaya çalıșır \\
\hline 2.2. Eksiklik & Hatanın bilgi eksikliğinden kaynaklandığı ileri sürülür \\
\hline 2.3. Kaza & Hatanın bir talihsizlik sonucu olduğu ifade edilir \\
\hline 2.4. İyi Niyet & Hata olmasına rağmen iyi niyet ile yapııı̆dğı belirtilir \\
\hline 3.Eylemin Olumsuzluklarını Azaltma & \\
\hline 3.1. Destekleme & $\begin{array}{l}\text { Hata olmasına rağmen etkinliğin iyi niteliklerine veya geçmișteki olumlu } \\
\text { yönlerine vurgu yapııır }\end{array}$ \\
\hline 3.2. Minimize Etme & Hata sonucunda zararın çok ufak olduğu ileri sürülür \\
\hline 3.3. Ayırt Etme & $\begin{array}{l}\text { Hatanın bașka firmaların yaptıkları benzer hatalardan daha az zarara neden } \\
\text { olduğu ileri sürülür }\end{array}$ \\
\hline
\end{tabular}




\begin{tabular}{|l|l|}
\hline 3.4. Üstünlük & $\begin{array}{l}\text { Etkinlik sonucunda elde edilen faydanın, hatadan kaynaklanan } \\
\text { zararlarından daha önemli olduğu ileri sürülür }\end{array}$ \\
\hline 3.5. İtham Edenlere Saldırma & $\begin{array}{l}\text { Hata ile ilgili suçlamalarda bulunanlar hakkında toplumdaki güvenilirliği } \\
\text { azaltılmaya çalıșlır }\end{array}$ \\
\hline 3.6. Tazminat & Mağdurlara tazminat ödeme veya zararların karșılanmasıdır \\
\hline 4. Düzeltici Eylem & Problemi çözülür ve problemin tekrar etmemesi için çalıșılır \\
\hline 5. Kabullenme & Hata için özür dilenmesidir \\
\hline
\end{tabular}

Kaynak: (Benoit, 1997:178-182).

1.İnkar: Bu stratejide kurum, yanlış bir şey yapmadığını ve kriz yaşamadığını savunur (Benoit, 1997: 177). Kurum stratejisini masumiyet üzerine kurarsa "biz yapmadık" anlayışı, yanlış anlaşııma üzerine kurarsa "bizi başkalarıyla karışıırdınız" anlayışı, suç atma üzerine kurarsa "onlar yaptı" anlayışı kullanılır. Kurum kriz ile bağlantısının ortaya çıkması durumunda zor durumda kalabilir. Bu nedenle suçu üçüncü kişilere atarken dikkat etmek gerekir (Suher, 2013: 120).

2.Sorumluluktan Kaçma: Bu strateji dörde ayrılmaktadır. Bunlar provokasyon, savunulabilirlik, kaza, iyi niyettir. Provokasyonda, kurum eylemin başkalarının saldırgan eylemlerine bir tepkidir. Kurumsal eylem bu provokasyona karşı mantıklı bir tepki halidir. Savunulabilirlikte, kurum olayın önemli bileşenleri üzerinde kontrol sahibi değildir ve enformasyon eksikliği olduğunu ifade eder. Kaza stratejisinde, kurum hedef kitleyi krize neden olayın tesadüfi ya da kazara olduğuna ikna etmeye çalışır. Kurum krizi yaşadığını ancak iyi niyetli olduğunu, krize neden olan olayı amaçlamadıklarını iddia eder (Çakır, 2014: 87-89).

3.Saldırganlığı Azaltma: Suçlanan kurum olayın algılanan olumsuzluklarını azaltmaya çalışabilir. Bu stratejide destekleme, minimizasyon, farklılaştırma, ayırt etme, suçlayana saldırmak, tazminat olmak üzere altı strateji vardır (Çakır, 2014: 88).

4.Düzeltici Eylem: Bu stratejide krize neden olan problemin düzeltileceği, bir daha tekrarlanmaması için çalışılacağı ifade edilir. Bu strateji ile hedef kitle, kurumun problemi düzeltme ya da önleme arzusunda olduğu algısına, bu algılarda zarar gören imajın düzeltileceğine ikna edilmeye çalışılır (Çakır, 2014: 89). Hedef kitlelerin düzeltici eylem stratejisi kapsamında sunduğu vaadlerin gerçekten kurum tarafından gerçekleştirip gerçekleştirilmediği takip edilmelidir (Benoit, 2000: 42).

5.Kabullenme: Kurum krizdeki sorumluluğu kabul eder ve af diler (Hearit, 2007: 173). Kurum, özür dilediğinde halk karşısında suçluluk kabul edilmiş ve af dilemiş olur. Kurum eğer açık bir şekilde suçluysa, bu stratejinin kullanılması gerekir (Suher, 2013: 122). Ancak kabullenme aynı zamanda gereğini yapma zorunluluğu getirir. Bu yüzden kurumlar krizi kabullenmek istemezler (Çakır, 2014: 82). Eğer kurum krizin ortaya çıkmasında suçlu ise, özür dilemede ne çok erken davranmalı ne de çok geç kalmalıdır. Zamanında ve doğru mesajlarla krizden zarar görenlerden özür dilemelidir. Kurum hatasını düzeltmek için imaj ve itibarını yeniden kazanmak için düzeltici eylem stratejisini kullanmalıdır. Kurum eğer haklı değilse, asla inkar stratejisini kullanmamalıdır. Çünkü inkar stratejisi gerçeklerin ortaya çıkması ile kurumu zor durumda bırakabilir 
ve itibarını zedeleyeceği gibi bu süreçte kuruma güven de azalabilir. Sorumluluktan kaçma stratejisi kurumları krizi görmemezliğe yönlendirerek tepki almalarına neden olabilir. Bu bağlamda krize neden olan hata varsa kabul edilmeli ve krizin olumsuzlukları azaltılmaya çalışılmalıdır.

\section{Sosyal Medya Kaynaklı Krizlerin 〈İmaj Restorasyon Teorisi Açısından Örnek Olaylar Üzerinden İncelenmesi}

Çalışmada sosyal medya aracılığıyla paylaşılan mesajlar nedeniyle ortaya çıkan ve takipçiler tarafından tepki çeken krizler seçilmiştir. Seçilen krizler imaj restorasyon teorisi çerçevesinde incelenmiş ve ardından kurumların kriz karşısında hangi tepki stratejilerini kullandıkları, kullanılan stratejilerin benzer ve farklı yönleri ortaya konulmuştur.

\subsection{Araștırmanın Yöntemi}

Çalışmada öncelikle literatür taraması yapılmış, sosyal medyanın kurumlar açısından avantaj ve dezavantajları, sosyal medya ve kriz yönetimi, imaj restorasyon teorisi ardından sosyal medya kaynaklı krizler incelenmiştir. Krizin hangi sosyal medya aracında ortaya çıktığı, krizin hangi mesaj ile ya da hangi olayla başladığı, kurumların krizi nasıl yönettiği, kullanılan kriz tepki stratejisi araştırılmıştır.Çalışmada krizler internet ortamında araștırılmış, literatür taramasından sonra veriler değerlendirilmiștir. Elde edilen verilerin değerlendirilmesinde Aktan'ın (2006) 5N-1K analizinden yararlanılmıştır. Aktan'ın "Organizasyonlarda Yanlış Uygulamalara Karşı Bir Sivil Erdem, Ahlaki Tepki ve Vicdani Red Davranışı: Whistleblowing" konulu yaptığı çalışmada örnek olaylar ne, nerede, hangi mecrada, ne zaman, neden sorularına yanıt aranacak şekilde incelenmiştir.

\subsection{Araștırmanın Önemi}

Sosyal medyada kriz yönetimi ile ilgili çalışmalar sınırlıık oluşturmaktadır. Kriz iletişiminde sosyal medyanın rolü ile ilgili çok fazla çalışılma olmadığı için sosyal medyanın, kriz anında yapacağı etkiler tam olarak bilinememektedir (Ward, 2011: 2-3). Sosyal medya ve kriz yönetimi ile ilgili literatür sınırlıdır. Bu bağlamda sosyal medya kaynaklı krizlerin nasıl yönetildiği, sosyal medya kaynaklı krizlerin benzer ve farklı yönlerinin ortaya konulması alana katkı sağlayacaktır.

\subsection{Araștırmanın Sınırlılıkları}

Çalışma sosyal medyada meydana gelen krizlerle ve örnek olaylar üzerinden değerlendirildiği için sınırlılık oluşturmaktadır. Ayrıca çalışmada seçilen krizler 2009-2017 yılları arasında meydana gelmiştir. Bu yılların seçilme nedeni güncel krizlerin seçilmesi ve sosyal medyada meydana gelen krizlerin son yıllarda yaygınlık göstermesi nedeniyledir. Bu yıllar arasında başka birçok kriz yaşanmıştır ancak bunlar sosyal medyada paylaşılan içerikler nedeniyle krize neden olmadığı için (başka faktörler nedeniyle ortaya çıktığı için) çalışma dışında tutulmuştur. Kriz önce başka mecralarda başlamış ve daha sonra sosyal medyaya taşınmışsa bu krizler çalışmaya dahil edilmemiştir. Bu çalışmada sadece sosyal medyada başlayıp, sosyal medyada yönetilen ve sona eren krizler seçilmiştir. Bu yönüyle de çalışma sınırlıdır. 


\subsection{Araștırmanın Soruları}

Çalışmanın amacını ortaya koymak ve soruların cevaplarını bulmak için literatür taraması yapılarak sorular oluşturulmuştur:

Sosyal medyada meydana gelen sosyal medya kaynaklı krizler hangileridir?

$>\quad$ Çalışma için seçilen krizler, hangi mecrada, ne zaman, ve nasıl yönetilmiştir?

Krizde kullanılan tepki stratejilerinin benzer ve farklı yönleri nelerdir?

\section{Bulgular}

Tablo-2: Krizin Kaynağı Sosyal Medya Aracı

\begin{tabular}{|l|c|c|c|}
\hline \multicolumn{1}{|c|}{ Dünya } & Facebook & Twitter & Youtube \\
\hline 1) Kenetth Cole & & $X$ & \\
\cline { 1 - 1 } 2) Chrysler & & $X$ & \\
\cline { 1 - 1 } 3) Vodafone & & $X$ & \\
\hline 4) Red Cross & & $X$ & \\
\hline 5) Quantas & & $X$ & \\
\hline 6) Entenmann & & $X$ & \\
\hline 7) ) Starbucks & $X$ & $X$ & \\
\hline 8) Domino's Pizza & $X$ & & $X$ \\
\hline 9) KitchenAid & & $X$ & \\
\hline 10) Burger King Marul Krizi & & $X$ & \\
\hline 11) Burger King Hack Krizi & & $X$ & \\
\hline 12) CNN & & $X$ & \\
\hline 13) Gilbert Gottfried & & $X$ & \\
\hline 14) Nestle (Greenpeace Video) & $X$ & & $X$ \\
\hline Türkiye & & & \\
\hline 15) Onur Air (Van Depremi) & $X$ & $X$ & \\
\hline 16) Doğadan Çay & & $X$ & $X$ \\
\hline 17) Hasbro Oyun Kulübü & $X$ & & $X$ \\
\hline 18) Yildız Holding & & $X$ & $X$ \\
\hline 19) Yașar Holding & & \\
\hline
\end{tabular}

Sosyal medya kaynaklı krizlerin en fazla Twitter'da $(n=15)$ yaşandığı görülmektedir. Ardından sırasıyla Facebook ve Youtube $(n=3)$, Twitter ve Youtube $(n=2)$, Facebook ve Twitter $(n=2)$, Facebook $(n=1)$ yer almaktadır. 
Tablo-3: Krize Neden Olan Mesaj ve Olayların İçeriği

\begin{tabular}{|c|c|}
\hline \multicolumn{2}{|l|}{ Dünya } \\
\hline 1) Kenetth Cole & $\begin{array}{l}\text { Giyim mağazası Kenetth Cole, Mısır'da demokrasi direnișler yașanırken, Twitter’da } \\
\text { direniș ile ilgili dalga geçen bir mesaj attı. Mağaza, Kahire sokaklarındaki insanların } \\
\text { nedeninin markanın yaptığı indirime bağlamıș ve komik olduğu belirtilmiștir. }\end{array}$ \\
\hline 2) Chrysler & $\begin{array}{l}\text { Șirketin resmi hesabından “Burası arabalar șehri olarak bilinen Detroit ama burada } \\
\text { kimse s- araba kullanmasını bilmiyor” paylașildı. }\end{array}$ \\
\hline 3) Vodafone & Vodafone Twitter hesabında “homo” kelimesi ile ilgili bir tweet paylaștı. \\
\hline 4) Red Cross & $\begin{array}{l}\text { Sosyal medya uzmanı kendi hesabının yerine marka hesabından paylaștı̆ı } \\
\text { "Arkadașım Ryan Dogfish Head birasının dörtlü paketinden iki tane daha bulmuș. } \\
\text { Biz içersek adam gibi içeriz" mesajı paylaștı. }\end{array}$ \\
\hline 5) Quantas & $\begin{array}{l}\text { Șirket, çalıșanları açlık grevi yaparken, sosyal medyadan neșeli bir yarıșma } \\
\text { bașlattı. Bledisloe Kupası maçı iç̦in bilet kazanmak isteyenlere Twitter'da soru } \\
\text { sordu ve kazanan takipçilerine Oyuncu Radike Samo gibi giyinme sözü verdi. }\end{array}$ \\
\hline 6) Entenmann & $\begin{array}{l}\text { Twitter'da ürünlerinin tanıtımı için suçlu değil anlamında olan \#notguilty etiketini } \\
\text { kullandı. Bu etiket Casey Anthony davasını takip eden Twitter kullanıcıları } \\
\text { tarafından da kullanıııordu. Șirket duyarlı olunması gereken bir konuya ticari } \\
\text { kaygı ile yaklaștığı için eleștirildi. }\end{array}$ \\
\hline 7) I Starbucks & $\begin{array}{l}\text { Starbucks, Arjantin’de orijinal Starbucks bardakları yerine Arjantin üretimi } \\
\text { bardakları kullandıklarını ve bunun için müșterilerinden özür dilediklerini ifade } \\
\text { eden bir tweet paylaștı. }\end{array}$ \\
\hline 8) Domino’s Pizza & $\begin{array}{l}\text { İki çalıșan sağlık ve hijyen koșullarını yok sayarak müșterilere pizza ve sandviç } \\
\text { hazırladı ve birbirlerini videoya çekerek, görüntüleri Youtube’a yüklediler. }\end{array}$ \\
\hline 9) KitchenAid & $\begin{array}{l}\text { ABD'de bașkanlık seç̦imleri sürerken șirket çalıșanı șirketin resmi Twitter } \\
\text { hesabından “Obama'nın anneannesi bile bunun kötü olacağını biliyordu. Torunu } \\
\text { bașkan olmadan } 3 \text { gün önce vefat etti” yazıı Obama'yı așağılayan bir tweet atıldı. }\end{array}$ \\
\hline 10) Burger King Marul Krizi & $\begin{array}{l}\text { Burger King'in bir çalıșanı, marul kutularının üzerine basarken fotoğrafını çekip } \\
\text { sosyal medyada paylaștı. Bu görüntü 'Burger King'de yediğiniz marul' bașlığılala } \\
\text { haber sitelerinde yer alınca kriz yașandı. }\end{array}$ \\
\hline 11) Burger King Hack Krizi & $\begin{array}{l}\text { Resmi twitter hesabı saldırgan ya da saldırganlar tarafından hacklenerek, } \\
\text { Mcdonalds mesajları ile dolduruldu ve hesabın ismi Mcdonalds olarak değiștirildi. }\end{array}$ \\
\hline 12) CNN & $\begin{array}{l}\text { CNN'in editörü Octavia Nasr, Hizbullah'ın Șii lideri Ayatollah Muhammed Hüseyin } \\
\text { Fadıllah'a karșı duyduğu saygısını tweetinden dile getirdi. }\end{array}$ \\
\hline 13) Gilbert Gottfried & $\begin{array}{l}\text { Japonya’da yașanan depremin ardından Gilbert Gottfried, “Japonlar çok gelișmiș, } \\
\text { denize gitmiyorler, deniz onlara geliyor” mesajını paylaștı. }\end{array}$ \\
\hline 14) Nestle & $\begin{array}{l}\text { Greenpeace, Kit-Kat'ın ünlü sloganı “Bir ara ver, bir Kit Kat ye” sloganını } \\
\text { kullanarak orangutanların vahșice katledilmesi ve yağmur ormanlarının yok } \\
\text { edilmesi ile ilgili videolar hazırlayıp yayımladı. Nestlenin ürünlerinde kullandığı } \\
\text { palm yağını ormanları yok ederek elde ettiği iddia edildi. }\end{array}$ \\
\hline \multicolumn{2}{|l|}{ Türkiye } \\
\hline 15) Onur Air & $\begin{array}{l}\text { Van’daki depremzedelere gönderilmek için Facebook'taki her takipçi için bağıș } \\
\text { yapacağını açıkladı ancak takipçilerden tepki çekti. }\end{array}$ \\
\hline
\end{tabular}




\begin{tabular}{|c|c|}
\hline 16) Doğadan Çay & $\begin{array}{l}\text { Youtube'ta yayınlanan “kadınlar ne ister” yeșil çay reklam filmi kadınlarla ilgili } \\
\text { "Çikolata ister, çiçek ister, sonra yine ayakkabı ister" gibi ifadeler içeren reklam } \\
\text { kamuoyunda, özellikle kadınlardan büyük tepki aldı. }\end{array}$ \\
\hline 17) Hasbro Oyun Kulübü & $\begin{array}{l}\text { Hasbro Oyun Kulübü, yılbașında «eğlenceyi dıșarıda arama" konulu bir reklam } \\
\text { hazırladı. Yılbașında sokakta atılan her adımın diğer günlere kıyasla çok daha } \\
\text { pahalıya mal olduğu, tek bașına sokakta dolașmanın tehlikeli olduğu ima } \\
\text { edilen reklam cinsel istismar olarak algılandı ve tepki çekti. Reklamın yayından } \\
\text { kaldıııması için imza kampanyası bașlatılıld. }\end{array}$ \\
\hline 18) Yıldız Holding & $\begin{array}{l}\text { Dijital teknoloji ile hazırlanan animasyon reklam, TV ve sosyal medyada yayınması } \\
\text { üzerine toplumda bazı kesimler tarafından politik bir mesaj olarak algılandı. }\end{array}$ \\
\hline 19) Yașar Holding & $\begin{array}{l}\text { “Evet doğru karar veren Türk halkına șükranlar” mesajııın paylașılması, tepkiler } \\
\text { üzerine mesajın silinmesi ve silinen mesaja tekrar tepki gösterilmesi krize neden } \\
\text { oldu. }\end{array}$ \\
\hline
\end{tabular}

Tablo 3'te paylaşıldığı gibi sosyal medyada krizler paylaşılan mesajlar nedeniyle ortaya çıkabilmektedir. Yanlış söz, kelime ya da cümlelerin kullanılması, mesajın yanlış zamanda paylaşılması krizlere neden olabilmektedir.

Tablo-4: Sosyal Medyada Kurumların Kullandığı İmaj Restorasyon Stratejileri

\begin{tabular}{|c|c|c|c|c|c|}
\hline Dünya & $\begin{array}{l}\text { Kabullenme } \\
\text { (Özür Dileme) }\end{array}$ & $\begin{array}{l}\text { Sorumluluktan } \\
\quad \text { kaçma } \\
\text { (provokasyon, } \\
\text { eksiklik, kaza, } \\
\text { iyi niyet) }\end{array}$ & $\begin{array}{c}\text { Olumsuzlukları } \\
\text { Azaltmaldestekleme, } \\
\text { minimize etme, ayırt } \\
\text { etme, üstünlük, itham } \\
\text { edenlere saldırma, } \\
\text { tazminat }\end{array}$ & $\begin{array}{l}\text { Düzeltici } \\
\text { Eylem }\end{array}$ & İnkar \\
\hline 1) Kenetth Cole & $x$ & & $x$ & & \\
\hline 2) Chrysler & $x$ & & $x$ & $X$ & \\
\hline 3) Vodafone & $x$ & & $x$ & $x$ & \\
\hline 4) Red Cross & $x$ & & $x$ & & \\
\hline 5) Quantas & $x$ & & $x$ & & \\
\hline 6) Entenmann & $x$ & & $x$ & & \\
\hline 7) I Starbucks & $x$ & $x$ & $x$ & & \\
\hline 8) Domino’s Pizza & $x$ & & $x$ & $x$ & \\
\hline 9) KitchenAid & $x$ & & & & \\
\hline 10) Burger King Marul Krizi & $x$ & & & $x$ & \\
\hline 11) Burger King Hack Krizi & $x$ & & & & \\
\hline 12) CNN & $x$ & & $x$ & $x$ & \\
\hline 13) Gilbert Gottfried & $x$ & & $x$ & $x$ & \\
\hline 14) Nestle & & & $x$ & $x$ & $x$ \\
\hline Türkiye & & & & & \\
\hline
\end{tabular}




\begin{tabular}{|l|c|c|l|l|l|}
\hline 15) Onur Air & $X$ & $X$ & & & \\
\hline 16) Doğadan Çay & $X$ & $X$ & & & \\
\hline 17) Hasbro Oyun Kulübü & $X$ & & & & \\
\hline 18) Yıldız Holding & $X$ & & & & $X$ \\
\hline 19) Yașar Holding & $X$ & $X$ & & & \\
\hline
\end{tabular}

Tablo 4'te görüldüğü gibi kurumlar, krizin etkisini azaltmaya yönelik çalışmalar yapmaktadırlar. İncelenen 19 krizde kurumun yöneticisi, çalışanı, sosyal medya uzmanı ya da CEO'su tarafından paylaşılan mesajlar krize neden olmuş ve takipçileri tarafından tepki çekmiştir. Krizin takipçiler üzerindeki etkisini azaltmak için 18 krizde kurum ya da kişiler krize neden olayı kabul ederek özür dilemiştir. Chrysler, Vodafone, Burger King marul krizi, Domino's Pizza, CNN, Gilbert Gottfried (Aflac) eylem olumsuzluklarını azaltma stratejileri çerçevesinde krizi minimize etme amaçı düzeltici eylem stratejisini kullanarak krizi bir daha yaşamamak için krize neden olan kişiyi/kişileri işten çıkarmıştır. Nestle de düzeltici eylem stratejisini kullanarak krizi yaşamamak için önlem almıştır. Yaşar holding, Hasbro Oyun Kulübü, Doğadan çay, Nestle, Onur Air, Starbucks, CNN, Gilbert Gottfield, Domino's Pizza, Entenmann, KitchenAid, Chrysler, Vodafone, Burger King Hack, Red Cross krize neden olan mesajı silerek krizin etkilerini azaltmayı planlamıştır.

Ülker markası sahibi Yıldız Holding yetkilileri, yaşanılan kriz nedeniyle yaptıkları açıklamada, "1 Nisan kapsamında hayata geçirdiğimiz 'küçük kardeş olmak' isimli kampanyamız maksatı olarak farklı noktalara çekilmeye ve içinde olmayan anlamlar yüklenmeye çalışılmaktadır. Kampanyamız 1 Nisan konsepti kapsamında aile bireyleri ve özellikle kardeşler arasındaki tatı rekabeti konu almaktadır. Sosyal medyada kast edilen hiçbir konuyla ilgili yoktur, olamaz. Bu masum şaka günü reklamını farklı noktalara çekenlerle ilgili tüm hukuki haklarımızı kullanacağımızı bildiririz’' ifadelerine yer verdi. Açıklamada maksatı olarak farklı noktalara çekildi iddiası suçu başkasına atma stratejisini kullandığını, açıklamada ifade edildiği gibi, kendilerine kumpas kurulduğu, haklarını savunacaklarını dile getiren şirket yetkililerinin, itham edenlere saldırma stratejisini kullandığı görülmektedir (Duğan ve Şahin, 2017: 970). Reklamın şaka içerikli olduğu ve iyi niyetle yapıldığı belirtilen açıklamada iyi niyet stratejisinin kullanıldığı görülmektedir. Ülker ikinci açıklamasında, “...... reklam filmlerimizin birisi ile ilgili şirketimize ve markamıza yönelik akıl almaz, mesnetsiz bir karalama kampanyası başlatıldı. ....Reklam film görüntüleri ve üzerindeki yazılarla oynanarak deformasyon oluşturuldu ve sanki bu deforme edilmiş görüntü ve sözler markamıza aitmiş gibi lanse edilmeye çalışıldı. Açıklamaya rağmen reklam filmine farklı anlamlar katmaya çalışan bu olumsuz kampanya, markamıza / şirketimize yönelik 'hakaret ve tehditler' içerecek kadar ileriye götürüldü. Ülker, 1944 yılından bu yana bu memleket için üreten, ürettikleri ile tüketicilerini memnun eden bir şirket olarak milletimizin ve memleketimizin önemli bir değeri olduğunun bilincindedir. Ve yine Ülker, milletimizin, Ülker'e verdiği değerin de bilincindedir. Aslında, Ülker'i hedef almış gibi görünmekle birlikte, haksız itham ve iftiralarla; devletine, milletine ve ülkesine bağı saygıdeğer vatandaşlarımızı da tahrik etme ve hasmane tutum almaya zorlamayı amaçlamıştır. Ayrıca şirketimiz tarafından konu ile ilgili kapsamlı bir soruşturma başlatılmış olup, ilgili kişilerin tamamı açığa alınmış olup, ihmali ve/veya kastı olan herkes hakkında idari tedbirlerin yanı sıra suç duyurusunda da bulunulacaktır. Bu vesile ile bu haksız algıdan incinmiş olan tüm 
vatandaşlarımızdan da ayrıca özür diliyoruz...” ifadeleri ile reklamda şaka yapıldığı ancak reklamın kurgulanarak tekrar yayınlandığı ifadesiyle suçu başkasına atma stratejisinin kullanıldığı görülmektedir. Ülkersin büyük bir şirket olduğu ve bu ülkenin değeri olduğu vurgulanarak hatanın etkisini azaltma amaçlı minimize etme stratejisi tercih edilmiş ve şirket son açıklamasında krizi kabullenerek, özür diledi. Konuyla ilgili Ali Saydam gazete köşesinde şu görüşlere yer verdi: "Krizde ilk reaksiyonu veremeyen şirket, krize neden olan ortamı iyi analiz edememiş, hasar tespiti ve ölçümleme yapmamış, konuyla ilgili açıklama yapılırken sadece krizin geldiği dijital ortam değil, bütün analog kanallar kullanılmış ve dolayısıyla kriz daha da büyümüş, komployu kim, kime yapmış açıklanamamıştır" (Ali Saydam, Yenişafak, 2017). Yine zamanlamanın sosyal medyada önemi açısından benzer bir olay daha yaşandığı görülmektedir.

Quantas havayolu şirketi, çalışanları açlık grevindeyken sosyal medya hesabından neşeli bir yarışma başlattı, tepki üzerine şirket özür mesajı yayınladı (https:// mumbrella.com.au/qantas-apologises-after-giving-tickets-to-blackface-fans-55889). Onur Air sosyal medya krizinde kurumun Van'daki depremzedelere gönderilmek amacıyla Facebook'taki her takipçi için bağış yapacağını açıklaması üzerine takipçiler kurumu fırsatçılıkla suçlayarak tepki gösterdi. Tepki üzerine açıklama yapan kurum, "...kampanyamız bunu anlayamayan bazı takipçilerimiz nedeniyle sona ermiştir..... Yanlış anlamalar için yanlış anlamayan takipçilerimizden özür dileriz." ifadelerine yer verdi ve bu açıklama üzerine sosyal medyada tepki arttı. Tepki üzerine kurum yine yanlış anlaşılmalar için özür diledi. Krizi önce ajans ardından kurum temsilcileri yönetti. Takipçilerin taleplerinin yanıtsız kalması, hızlı aksiyon alınamaması, sosyal medyadaki tepkilerin silinmesi, kurumun saldırgan davranması, takipçilerin suçlanması (Bat ve Yurtseven, 2016: 212-217) krizin daha da büyümesine neden oldu. Onur Air ilk başta takipçilerine saldırarak (itham edenlere saldırma stratejisi) sorumluluktan kaçmaya çalışmış, kampanyanın iyi niyetle (iyi niyet stratejisi) yapıldığını ifade etmiş ve en sonunda hatasını kabul ederek, özür dileme stratejisini kullanmıştır. Toplumun hassasiyeti nedeniyle ortaya çıkan krizlerden birini de CNN yaşadı. CNN'in Ortadoğu editörü, Hizbullah'ın Şii lideri Ayatollah Muhammed Hüseyin Fadıllah'a karşı duyduğu saygısını tweetinden dile getirince tepki çekti ve görevinden alındı, CNN çalışanlarının sosyal medya hesaplarını nasıl kullanacakları ile ilgili hazırladıkları yönetmeliği çalışanları ve takipçileriyle birkez daha paylaştı (https://medyasyon.wordpress.com).

CNN, bu krizde düzeltici eylem stratejisini kullanarak, sorunun bir daha yaşanmaması için çalışanları ve takipçilerine yönetmeliği tekrar hatırlattı. Entenmann şirketi Casey Anthony davasında takipçiler tarafından kullanılan \#notguilty etiketini kullanarak tepki çekti, toplumun hassas olduğu bir konuda duyarsız davranılması şirketin özür dilemesi ve etiketi kaldırması ile kriz sona erdi (https://medyasyon.wordpress.com). Entenmann şirketi, bu krizde özür dileme stratejisini kullandı. Starbucks'ın yaşadığı krizde aynı toplumsal hassasiyetin gösterilmediğini ortaya koymaktadır. Arjantin'de, Arjantin üretimi bardakları kullandıkları için müşterilerinden tweet hesabı üzerinden özür dileyen şirket büyük tepki çekti. Tepki üzerine olayı kabullenip özür mesajı yayınlayan şirket, Facebook hesabından niyetlerinin bir iç planlama hatası sonucu meydana gelen sorun hakkında müşterilerini bilgilendirmeyi amaçladıklarını ifade ederek (https:// thenextweb.com/la/2012/07/16/starbucks-apologizes-to-its-argentine-customers-ontwitter-and-facebook-creates-pr-crisis/), iyi niyet stratejisini kullandı ve tepki üzerine olayı kabul ederek, özür dileme mesajı yayınladı. Yine toplumsal hassasiyetin gözardı edildiği ve sosyal medya hesabından "Yılbaşında Eğlenceyi Dışarda Arama" mesajı 
ile reklam yayınlanan Hasbro Oyun Kulübü, tepki üzerine reklamı yayından kaldırdı, "Yılbaşına özel hazırladığımız kampanya videomuza gelen geri bildirimleri takip ediyoruz. Oluşan hassasiyeti dikkate alarak videoyu yayından kaldırdığımızı ve gelinen noktadan büyük üzüntü duyduğumuzu belirtmek isteriz. Rahatsızlık duyan herkesten özür dileriz." açıklaması ile kamuoyundan özür diledi. Gilbert Gottfried Japonya'da 2011 yılında yaşanan deprem ile ilgili "Japonlar çok gelișmiş. Denize gitmiyorlar, deniz onlara geliyor." tweeti paylaşması üzerine tepki çekti, Gottfried, hesabından, "Japonya'daki trajediyle ilgili mizahımdan dolayı rahatsız olan herkesten içtenlikle özür dilerim. Saygısızıı etmek istemedim." mesajını paylaştı. Ardından Gilbert'in özel bir şirketteki görevine son verildi ve şirket, "Bu düşünceler herkesin düşünce ve duygularını temsil etmiyor. Bu zor zamanlarda merhamet ve endişe dışında hiçbir şeye yer yok." açıklamasını yaptı (https://www.huffingtonpost.com). Krizin bir daha yaşanmaması için krize neden olan kişinin işten çıkartılması şirketin düzeltici eylem stratejisini kullandığını göstermektedir. Giyim mağazası Kenetth Cole, Mısır'da demokrasi ile ilgili direnişler yaşanırken, Twitter'da bu olaylarla dalga geçen bir mesaj paylaştı ve tepkiler üzerine özür mesajı yayınladı (http://www.dailymail.co.uk/news/ article-1353376/Egypt-twitter-Kenneth-Cole-sparks-outrage-bad-taste-tweet-Cairoriots.html). Chrysler, resmi hesabından "Burası arabalar şehri olarak bilinen Detroit ama burada kimse s- araba kullanmasını bilmiyor." mesajının paylaşılması üzerine tepki karşısında özür yayınlayan şirket, sosyal medya uzmanının görevine son verdi.

Benzer bir kriz de Vodafone yaşadı. Vodafone Twitter hesabından "homo" kelimesini paylaşması üzerine tepki çekti, şirket kısa sürede mesajı silerek özür dileme mesajı yayınladı ve sosyal medya hesabını yöneten çalışanı işten çıkardı (https://medyasyon. wordpress.com). Chrysler ve Vodafone krize neden olan kişiyi işten çıkartarak düzeltici eylem stratejisini kullanmıştır. Red Cross'un sosyal medya uzmanı kendi hesabı yerine marka hesabından paylaştığı "Arkadaşım Ryan Dogfish Head birasının dörtlü paketinden iki tane daha bulmuş. Biz içersek adam gibi içeriz." mesajı tepki çekmesi üzerine mesaj silindi ve takipçilerden özür dilendi (https://melissaagnes.com/themakings-of-a-great-social-media-crisis-plan-the-red-cross/).

Nestle krizi önce inkar etmiş, doğaya karşı sorumluluklarını aksattığını kabul etmemiş, resmi Facebook hesabında birçok olumsuz yorumun paylaşılması üzerine fanların profillerini silme tehdidiyle karşılık vermiş, bunun sonucunda kriz daha da büyümüştür. Daha sonra krize neden olan ve Greanpeace'in yayınladığı videonun telif haklarının çiğnendiği gerekçesiyle videoyu yayından kaldırtmış, Greenpeace'in resmi sitesinde, Vimeo, Facebook gibi sosyal paylaşım ağlarında video yayınlanmaya devam etmiştir. Nestlenin sayfasındaki bu olumsuz içerikleri silmeye çalışması protestocuların daha yoğun tepkisine neden oldu. Ancak Nestle yetkilileri, krizden bir yıl sonra Pete Blackshaw ile pazarlama ve iletişim stratejilerini değiştirdi, sosyal medyayı 24 saat takip etti ve tepkiyi azaltmaya yönelik düzeltici eylem stratejisini kullandı, Nestle sorumluluk alarak kriz sonrasında tedarikçilerini, paydaşlarını, bölge halkını, kamuoyunu yaptığı çalışmalarla ilgili bilgilendirdi. Nestle, internet aracılığıyla yılık raporlarında sürdürülebilir palm yağı üretimi ile ilgili verileri paylaştı, kriz sonrası TFT ve Green Palm örgütlerinin üyelik şartları doğrultusunda şeffaflık, tedarik ve üretim süreçlerinde dönüşümü taahhüt etti. Strateji değiştiren Nestle gerekli adımları attı ve krizi fırsata çevirdi. Greenpeace uzmanları ile yapılan görüşmeler, kamuoyuna yapılan açıklama ve ilanlar Nestle'nin itibarını korumasında katkı sağladı. Nestle'nin ilk zamanlar krizi iyi yönetemediği, daha sonra yönetimsel kararları ve halkla ilişkiler faaliyetleriyle kriz 
yönetiminde başarılı olduğu görülmektedir (Somers ve Enders, 2012, Financial Times; Çubukçuoğlu, 2017: 183).

Domino's Pizza krize başlangıçta sessiz kaldı, ardından sosyal medyada açıklama yaptı. Domino's Pizza CEO'su Patrick Doyle, youtube üzerinden açıklama yaparak, kamuoyundan özür diledi. Müşterilerle iletişim kurabilmek için sosyal medyada yeni bir hesap açıldı, şirketin kendi web sayfasında sorular cevaplandı ve krizin anlatılığı özel bir link oluşturuldu. Söz konusu çalışanlar işten çıkartıldı, sosyal medya ekibi kuruldu, şikayetlere zaman kaybetmeden yanıt verildi, ayrıca geleneksel medya ile iletişim kurularak açıklama yapıldı (Suher, 2013: 138; https://capital.com.tr). Domino's Pizza özür dileme stratejisini zamanında kullanarak hatasını kabul etti ve eylemin olumsuzluklarını azaltmak ve bir daha benzer krizi yaşamamak için düzeltici eylem stratejisini kullandı. Doğadan Çay, "kadınlar ne ister" konulu reklamında cinsiyet ayrımcılığına neden olduğu gerekçesiyle tepki çekti, konu ile ilgili imza kampanyası başlatılması üzerine yetkililer şu açıklamayı yaptı: "Yeni ürünümüzü duyurmak amacılla hazırladığımız kampanya videomuz için sosyal medyada yapılan yorumlar bizi derinden üzdü. Bahsedilen amaçla yola çıkmadığımızı içtenlikle belirtmek isteriz. Bu nedenle siz değerli tüketicilerimiz nezdinde oluşan hassasiyeti anladığımızı ve kampanya videomuzu yayından kaldırdığımızı bildiririz." açıklamada iyi niyet stratejisini kullanan şirket, özür dileme stratejisini kullanarak krizin etkisini minimize etmeye çalıştı. Referandumda oylanan Cumhurbaşkanlığı hükümet sisteminin yüzde 51.41 "evet" oyuyla kabul edilmesinden sonra Yaşar Holding Yönetim Kurulu Başkanı M. Selim Yaşar, Facebook'taki hesabından "Evet doğru karar veren Türk halkına şükranlar." mesajını paylaşmış tepki üzerine mesajı sildi. Mesajı silmesine tepki gösterilmesi üzerine "Karşıyaka zarar görmesin diye silmiştim, 45 milyon borcu olduğu gibi biline." mesajını paylaşan Başkan Yaşar’a bir takipçisi "Siz Karşıyaka'yı düşünmeyin. Yaşar Holding”i düşünün” mesajına Başkan Yaşar tekrar, "En yüksek hayır Karşıyaka'dan düşünüyorum ve Ankara ile ters düşmemek için sponsorluğu yeniden gözden geçirmek gerekli." cevabını paylaştı. Başkan Yaşar, Facebook hesabından son olarak "Karşıyaka spor camiasından özür dilerim, ben kimseyi kırmak istemem ve herkesin kararına saygılıyım." açıklamasını paylaştı. Ardından, "Yaşar topluluğu Yönetim Kurulu Başkanı Sayın Selim Yaşar'ın 16 Nisan 2017 Pazar günü gerçekleşen referandum sonrası, kişisel sosyal medya hesabından yapmış olduğu paylaşım üzerine açıklama yapma gereği duyulmuştur. Yaşar Topluluğu, 71 yıldır kurumsal değerleri ışı̆̆ında, etik duruşundan taviz vermeden, her kurum, kuruluş ve bireye eşit mesafede durarak şirketleri ve markaları ile üretmeye, istihdam sağlamaya ve ülkemizi ekonomisine katkı sağlamaya devam etmektedir. Demokrasini önemi ve gereğine inanan Yaşar Topluluğu olarak, Sayın Selim Yaşar'ın görüşlerini şahsi görüşleri olduğunu, söz konusu görüşlerin Yaşar Topluluğu ve ailesini temsilen vermediğini, topluluğumuzun tüm siyasi görüşlere ve partilere eşit mesafede durduğunu hatırlatmak isteriz. Ülkemizin gelişmesi ve geleceği için var gücümüzle çalışmaya devam edeceğiz..." açıklamasını yapan şirket yetkilileri, eylemin olumsuzluklarını azaltma amaçlı destekleme stratejisini kullanarak, şirketin ülkeye katkısından bahsetmiştir.

Şirketin yönetim kurulu başkanı sosyal medyadan paylaştığı içeriklerde ilk önce itham edenlere saldırarak tehdit etmiş, ardından tepkiler üzerine hatasını kabul ederek özür dilemiştir. Burger King'in bir çalışanı, marul kutularının üzerine basılarak çekilmiş fotoğrafın üzerine, "Burger King'de yediğiniz marul budur" yazıp paylaşınca, şirket tarafından işine son verildi (www.dailymail.co.uk). Burada krize neden olan kişi işten 
çıkarılarak sorunun bir daha yaşanmaması için düzeltici eylem stratejisinin kullanıldığı görülmektedir. Burger King'in ikinci krizinde resmi twitter hesabı hacklendi ve sayfa Mcdonalds mesajları ile dolduruldu. Yetkililer krizi fark edince, "Yöneticilerle, meşru sitemizi ve orijinal paylaşımlarımızı ortaya koyabilene kadar çalıştık. Sektörün diğer üyeleri ile ilgili uygunsuz konular hakkında atılan tweetler ile karşılaşan hayranlarımız ve takipçilerimizden özür diliyoruz." mesajını paylaştı (https://bigumigu.com). ABD'de başkanlık seçimleri sürerken KitchenAid şirketinin resmi Twitter hesabından "Obama'nın anneannesi bile bunun kötü olacağını biliyordu. Torunu başkan olmadan 3 gün önce vefat etti." mesajının paylaşılması üzerine şirketin CEO'su özür mesajı yayınladı (https://adversion.com.tr/blog/dijitalitibar).

\section{Sonuç}

Kurumların belirli dönemlerde kriz ile karşılaşmaları olağandır. Ancak önemli olan kurumun krizi yönetebilme becerisini ortaya koyabilmesidir. Günümüzde kriz artık sadece geleneksel medyada gündeme gelmemekte sosyal medyada da hızla yayılmaktadır. Sosyal medya birçok avantajı ile kurumlara kolaylık sağlamanın yanı sıra iyi yönetilmediğinde birçok olumsuzlukları ortaya çıkmaktadır. Yapılan bu çalışmada bazı kurumların krizi başarıyla atlattığı görülürken, bazılarının ise iyi yönetemediği görülmektedir. Krizin en fazla Twitter'da yaşandığı ortaya çıkmıştır. İncelenen 19 krizde kurumun yöneticisi, çalışanı, sosyal medya uzmanı ya da CEO'su tarafından paylaşılan mesajlar krize neden olmuş ve takipçileri tarafından tepki çekmiştir. Krizin takipçiler üzerindeki etkisini azaltmak için 18 krizde kurum ya da kişiler krize neden olayı kabul ederek özür dileme stratejisini kullanmışlardır. Chrysler, Vodafone, Burger King marul krizi, Domino's Pizza, CNN, Gilbert Gottfried (Aflac) eylemin olumsuzluklarını azaltma amaçlı ve krizi bir daha yaşamamak için krize neden olan kişiyi işten çıkartarak düzeltici eylem stratejilerini kullanmıştır. Nestlenin krizi bir daha yaşamamak için düzeltici eylem stratejisi çerçevesinde sivil toplum kuruluşları ile birlikte hareket ederek önlemler aldığı görülmektedir. Yaşar holding, Hasbro Oyun Kulübü, Doğadan Çay, Nestle, Onur Air, Starbucks, CNN, Gilbert Gottfield, Domino's Pizza, Entenmann, KitchenAid, Chrysler, Vodafone, Burger King Hack, Red Cross krize neden olan mesajı silerek krizin etkilerini azaltmayı planlamıştır. Kenetth Cole, Chrysler, Vodafone, Red Cross, Quantes, Entenmann, Starbucks, CNN, Gilbert Gottfield, Onur Air, Hasbro Oyun Kulübü, Doğadan Çay, Ülker ve Yaşar holding kamuoyunun hassasiyetlerini analiz etmeden mesajlarını paylaşmış ve tepkilere neden olmuşlardır. Bu durum sosyal medyada paylaşılan mesajların zamanlamasının da önemli olduğunu göstermektedir.

Toplumun hassas olduğu konularda ve zor zamanlardan geçtiği günlerde paylaşılan mesajların içeriğine daha çok dikkat etmek gerekmektedir. Kriz yașayan Red Cross ve Domino's Pizza sosyal medyada hızlı tepki vererek doğru mesajlar oluşturup doğru iletişim araçlarını kullanarak başarılı olmuşlardır. Özellikle, sosyal medya platformuna bağlı olarak, şirketlerin krize tepki verirken farklı konularda vurgu yapmaları ve çeşitli iletişim stilleri kullanmaları gerekir (Corciolani vd., 2016: 43). Domino's Pizza başarılı bir iletişim dili kurarak krizi atlatmıştır. Geleneksel medya araçları dışında Facebook, Twitter, Youtube gibi sosyal ağ sayfalarından özür konuşması içeren video paylaşılması Dominos'un CEO'su Patrick Doyle'un yaptığı gibi faydalı olabilmektedir.Çalışmada incelenen veriler üzerinden değerlendirildiğinde kriz yaşayan kişi, kurum ve kuruluşlar krizin etkisini azaltma amaçlı öncelikle sosyal medya hesaplarından mesajları silmiş, ardından krize neden olan kişiyi işten çıkartarak düzeltici eylem stratejisini ve en sonunda 
da özür dileme stratejisini kullanmışlardır. Ünlü Amerikan istatistik profesörü William Edwards Deming'in dediği gibi "ölçemediğin şeyi yönetmezsin". Sosyal medyada var olmak için onu ölçümlemek ve yönetmek gerekir. Sosyal medyada çeşitli yöntem ve teknikler kullanarak halkla ilişkiler programlarının veya etkinliklerinin başarısı veya imaj yaratma sürecine katkısı ölçümlenebilmektedir (Göksel, 2013: 140). Bu ölçüm sonuçlarına göre strateji geliştirmenin daha doğru bir yöntem olacağı öngörülmektedir. Krizi öngörememe, hedef kitleyi iyi analiz edememe, hedef kitlenin gündemini takip edememe gibi olumsuzluklar kurumları kriz ile karşı karşıya getirmektedir. Her kurum sosyal medyada kriz ile karşılaşabilir. Ancak önemli olan krizi yönetebilme becerisini ortaya koyabilmektir. Sosyal medyada paylaşılan içeriklerin silinmesi, takipçilere tepki gösterilmesi, krize zamanında müdahale edememe, paylaşılan içeriklerin ve hedef kitlenin yeterince analiz edilememesi, kurumun yanlış stratejilerle krizi önlemeye çalışması krizin daha da büyümesine neden olmakta ve kurumun krizi yönetmesini zorlaştırmaktadır. Kurumların artık sosyal medyadan uzak durması mümkün değildir.

Dolayısıyla sosyal medyaya yönelik kriz senaryoları geliştirip, kriz ortaya çıkmadan proaktif bir yaklaşım benimsenerek, krize hazırlıklı olmak kurumlar için önem taşımaktadır. Kriz durumunda eğer hata söz konusu ise, özür dilenmeli ve kriz kabul edilmelidir. Ancak sürekli özür dileme stratejisinin kullanılması kuruma karşı güveni zedeleyebilir. Sosyal medya kaynaklı krizlerin örnek olaylar üzerinden imaj restorasyon teorisi açısından incelenen bu çalışma, bu haliyle sınırlılık oluşturmaktadır. Sosyal medya kaynaklı krizler diğer krize tepki stratejileri açısından da incelenebilir.

\section{Kaynakça}

Aktan, Coşkun Can (2006). "Organizasyonlarda Yanlış Uygulamalara Karşı Bir Sivil Erdem, Ahlaki Tepki ve Vicdani Red Davranışı: Whistleblowing." Mercek Dergisi. Ekim, 1-13.

Alikılıç, Özlem Aşman (2011). Halkla İlişkiler 2.0 Sosyal Medyada Yeni Paydaşlar, Yeni Teknolojiler. İstanbul: Eflatun.

Andrews, Simon, Gibson, Helen, Domdouzis, Konstantinos ve Akhgar, Babak (2016). "Creating Corroborated Crisis Reports From Social Media Data Through Formal Concept Analysis." Journal of Intelligent İnformation Systems. 47: 287-312.

Aslan, Pınar (2015). "Kriz İletişimi Yönetimi, Sosyal Medya ve Liderlik: Baltimore Olayları'nda Barack Obama ve Hillary Clinton'ın Twitter Mesajlarına Dair Bir İnceleme." İstanbul Üniversitesi İletişim Fakültesi Dergisi. 49: 15-30.

Bat, Mikail ve Yurtseven Turan, Çağla (2014). "Sosyal Medyada Kurumsal Kriz Yönetimi: Onur Air Örneği.” Gümüşhane Üniversitesi İletişim Fakültesi Elektronik Dergisi. 2(3): 197-223.

Benoit William L. (1997). "Image Repair Discourse and Crisis Communication." Public Relations Review. 23(2): 177-186.

Benoit, William L. (2000). "Another Visit to the Theory of Image Restoration Strategies." Communication Quarterly. 48 (1): 40-43.

Canpolat, Nesrin (2012). "Risk Toplumunda Halkla Illişkiler Şirketlerinin Kriz ve Kriz İleişimine 
Yönelik Bakış Açılarının Değerlendirilmesine Yönelik Bir Araştırma." Gümüşhane Üniversitesi İletişim Fakültesi Elektronik Dergisi, 3: 119-134.

Coombs, W. Timothy (2006). Code Red in the Boardroom: Crisis Management as Organizational DNA. Greenwood Publishing Group.

Coombs, W. Timothy (2009). "Conceptualizng Crisis Communication", Handbook of Risk and Crisis Communication (Ed. Robert L. Heath ve H. Dan O'Hair). New York: Routledge.

Coombs, W. Timothy (2010). "Parameters for Crisis Communication", The Handbook of Crisis Communication Malden (Ed. W.Timothy Coombs ve Sherry J. Holladay). MA: Wiley-Blackwell.

Corciolani, Matteo, Gistri, Giacomo ve Pace, Stefano (2016). "Exploring The Palm Oil Crisis Through The Lens of Different Social Media: An Analysis of Facebook, Youtube and Twitter Contents." Mercatie Competitivia. 4: 43-64.

Coombs W. Timothy ve Schmidt L. (2000)."An Empirical Analysis of Image Restoration: Texaco's Racism Crisis." Journal of Public Relations Research. 12 (2): 163-178.

Çakır, Vesile (2014). "Kriz Iletişimi Teorileri”, Kriz Yönetimi (Ed. Mustafa Akdağ ve Ümit Arklan). Konya: Literatürk.

Çetin, Muharrem ve Toprak, Yunus Emre (2016). "Kriz Illetişimi ve Sosyal Medya: Emisyon Krizinde Volkswagen'in Facebook Kullanımı." Selçuk İletişim Dergisi. 9 (3): 54-68.

Çınarlı, İnci (2016). Kriz İletişimi. İstanbul: Beta.

Çubukçuoğlu, Hasan Fürkan (2017). "Kurumsal Kuram Penceresinden Halkla Illişkiler: Nestle ve Palm Yağı Krizi.” İletişim Kuram ve Araştırma Dergisi. 44: 173-192.

Diyadin, Aslı ve Özdil, Tuncer (2017). "Krizlerle Baş Etmede Sosyal Medyanın Yeri ve Önemi." Ege Akademik Bakış. 17(3): 407-418.

Duğan, Özlem ve Şahin, Emine (2017). "İşletmelerde Kriz İletişimi: Ülker Şirketi’nin Krize Dönüşen "1 Nisan Reklamı" Üzerine Bir Araştırma." AL-FARABI 1. International Congress on Social Sciences. May 11-14, 957-973, Gaziantep.

Goodman, Michael B. (2006). "Corporate Communication Practice and Pedagogy at the Dawn of the New Millennium." Corporate Communications: An International Journal. 11(3): 196-213.

Gruber, Daniel A., Smerek, Ryan E., Thomas-Hunt, Melissa C. ve James, Erika H. (2015). "The Real-Time Power of Twitter: Crisis Management and Leadership in an Age of Social Media." Business Horizons. 58(2): 163-172.

Grundy, Michael ve Moxon, Richard (2013). "The Effectiveness of Airline Crisis Management on Brand Protection: A Case Study of British Airways." Journal of Air Transport Management. 28: 55-61.

Göksel, Ahmet Bülent (2013). Stratejik Halkla Illişkiler Yönetimi. Ankara: Nobel. 
Harris, Thomas L. ve Whalen, Patricia T. (2009). 21. Yüzyılda Pazarlama Profesyonellerinin Halkla Illişkiler El Kitabı. Çev., Serap Görpe. İstanbul: Rota.

Haşit, Gürkan (2013). Kriz Kavramı ve İşletmeler Açısından Kriz Yaratan Faktörler. Kriz İletişimi ve Yönetimi. Eskişehir: Açıköğretim Fakültesi Yayını No: 1776.

Hearit, Keith Michael (2007). "Corporate Deception and Fraud: The Case for an Ethical Apologia", In The Debate over Corporate Social Responsibility (Ed. Steve May, George Cheney and Juliet Roper). New York: Oxford University Press.

Jensen, Kristian Skriver (2014). Crisis Communication on Social Media. Yüksek Lisans Tezi: Aalborg University.

Kadıbeşegil, Salim (2003). Halkla İlişkilere Nereden Başlamalı.İstanbul: Mediacat.

Kalaycı, Beyza Nur (2017). Sosyal Medyada Kriz Illetişimi: Turkcell Örneği. I. International Conference on New Trends in Communication 1.Uluslararası İletişimde Yeni Yönelimler Konferansı, 331-341.

Kırdar, Yalçın ve Demir Otay, Filiz (2007). "Kriz Iletişimi Aracı Olarak İnternet: Kuş Gribi Kriz Örneği." İstanbul Üniversitesi İletişim Fakültesi Dergisi. 29: 93-106.

Kim, Sora, Zhang, Xiaochen Angela ve Zhang, Borui Warren (2016). "Self-mocking Crisis Strategy on Social Media: Focusing on Alibaba Chairman Jack Ma in China." Public Relations Review. 42: 903-912.

Koçak, Sevinç (2016). "Sosyal Medyada Kullanılan Mesajların Halkla Ilişkiler Çalışmalarındaki Önemi." The Turkish Online Journal of Design, Art and Communication. April. 6(2): 220-229.

Lin Xialing, Spence Patric R., Sellnow, Timothy L. ve Lachlan Kenneth A. (2016). "Crisis Communication, Learning and Responding: Best Practices in Social Media." Computers in Human Behavior. 65, 601-605.

Low Siew-Yoong, Yvonne, Varughese, Jeni ve Pang, Augustine (2011). Communicating Crisis: How Culture Influences Image Repair in Western and Asian Governments, Corporate Communications An International Journal. 16(3): 218-242.

Maresh-Fuehrer, Michelle M., ve Smith Richard (2016). "Social Media Mapping İnnovations for Crisis Prevention, Response, and Evaluation." Computers in Human Behavior. 54: 620-629.

Mitroff, I. Ian (2001). Managing Crises Before They Happen: What Every Executive \& Manager Needs to Know about Crisis Management. USA: Amacom.

Okay, Ayla ve Okay, Aydemir (2007). Halkla İlişkiler Kavram, Strateji ve Uygulamaları. İstanbul: Der .

Perry Danielle C., Taylor, Maureen ve Doerfel, Marya L. (2003). "Internet-based Communication in Crisis Management." Management Communication Quarterly. 17 (2): 206-232. 
Pira, Aylin ve Sohodol, Çisil (2004). Kriz Yönetimi-Halkla Illişkiler Açısından Bir Değerlendirme. İstanbul: Illetişim.

Sayar, Tahsin Eren ve Duğan, Özlem (2017). "Liderlerin Kriz Döneminde Sosyal Medya Kullanımı: Recep Tayyip Erdoğan Örneği.” Uluslar arası Hakemli İletişim ve Edebiyat Araştırmaları Dergisi. 15: 303-314.

Sayımer, İdil (2008). Sanal Ortamda Halkla İlişkiler. İstanbul: Beta.

Scott, David Meerman (2010). The New Rules of Marketing and PR.NJ: John Wiley \& Sons.

Somers, Aileen lonescu ve Enders, Albrecht (2012). How Nestle dealt with a social media campain against it. Financial Times. https://www.ft.com/content/90dbff8a-3aea-11e2-b3f0-00144feabdc0, 12.02.2018.

Suher, K. İdil (2013). Kriz lletişiminde Yeni Medya. Kriz Iletişimi ve Yönetimi. Eskişehir: Açıköğretim Fakültesi Yayını No:1776.

Sweetser, Kaye D. ve Metzgar, Emily (2007). "Communicating During Crisis: Use of Blogs as a Relationship Management Tool.” Public Relations Review. 33 (3): 340-342.

Tekvar, Sırma Oya (2016). Yeni Medya Yeni Halkla Illişkiler. Ankara: Karınca.

Tüz Vergiliel, Melek (1996). Kriz Döneminde İşletme Yönetimi. Bursa: Ekin.

Tüz Vergiliel, Melek (2004). Kriz Yönetimi. İstanbul: Alfa.

Valentini, Chiara ve Kruckeberg, Dean (2016). "The Future Role of Social Media in İnternational Crisis Communication", The Handbook of İnternational Crisis Communication Research (Ed. Andreas Schwarz, Matthew W. Seeger, Claudia Auer). John Wiley \& Sons, İnc.

Wang, Yan (2016). "Brand Crisis Communication Through Social Media: A Dialogue Between Brand Competitors on Sina Weibo." Corporate Communications: An International Journal. 21(1): 56-72.

Ward, Colleen (2011). Social Media And Crisis Communication: Are Organızations Using Social Media In Times of Crisis?, Masters Of Arts, Submitted To The Graduate School In Partial Fulfillment Of The Requirements, Bull State University. Indiana.

Yoo, Eunae, Rand, William, Eftekhar, Mahyar ve Rabinovich, Elliot (2016). "Evaluating İnformation Diffusion Speed and its Determinants in Social Media Networks During Humanitarian Crises." Journal of Operations Management. 45: 123-133.

https://medyasyon.wordpress.com/2012/05/31/en-buyuk-sosyal-medya-krizleri-ve-markalaramaliyeti/.Erişim tarihi: 14.02.2018.

https://www.capital.com.tr/capital-dergi/dijital/kriz-nasil-basariya-donustu-083883?sayfa=4. Erişim tarihi: 12.02.2018. 
http://www.pazarlamasyon.com/sosyal-medya-pazarlama/markalarin-sosyal-medya-krizleri-1/. Erişim tarihi: 20.01.2018

https://www.yenisafak.com/yazarlar/alisaydam/bir-kriz-nasil-yonetilmez-2037154.Erişim tarihi: 25.01.2018.

https://www.huffingtonpost.com/2011/03/14/gilbert-gottfried-fired-aflac_n_835692.html. Erişim tarihi:18.01.2018.

https://thenextweb.com/la/2012/07/16/starbucks-apologizes-to-its-argentine-customers-ontwitter-and-facebook-creates-pr-crisis/. Erişim tarihi: 20.01.2018.

http://www.dailymail.co.uk/news/article-1353376/Egypt-twitter-Kenneth-Cole-sparks-outragebad-taste-tweet-Cairo-riots.html. Erişim tarihi: 02.02.2018.

https://melissaagnes.com/the-makings-of-a-great-social-media-crisis-plan-the-red-cross/. Erişim tarihi: 02.02.2018.

http://www.dailymail.co.uk/news/article-2175053/Burger-King-worker-posted-pictures-standingbins-lettuce-fired.html. Erişim tarihi: 05.02.2018.

https://bigumigu.com/haber/burger-king-in-resmi-twitter-hesabi-ele-gecirildi/. Erişim tarihi: 10.02.2018. 